\title{
Deep Sequencing of The HIV-1 Polymerase Gene For Characterisation of Cytotoxic T-Lymphocyte Epitopes During Early And Chronic Disease Stages
}

\author{
Paballo Nkone \\ University of Pretoria \\ Shayne Loubser \\ University of the Witwatersrand \\ Thomas C. Quinn \\ National Institutes of Health \\ Andrew D. Redd \\ National Institutes of Health \\ Arshad Ismail \\ University of the Witwatersrand \\ Caroline T. Tiemessen \\ University of the Witwatersrand \\ Simnikiwe H. Mayaphi ( $\square$ sim.mayaphi@up.ac.za ) \\ University of Pretoria https://orcid.org/0000-0002-5453-4353
}

\section{Research}

Keywords: Illumina deep sequencing, Pol CTL epitopes, early HIV-1 infection, chronic HIV-1 infection, minority variants

Posted Date: November 16th, 2021

DOI: https://doi.org/10.21203/rs.3.rs-842193/v3

License: (c) (i) This work is licensed under a Creative Commons Attribution 4.0 International License. Read Full License 


\section{Abstract}

Background: Despite multiple attempts, there is still no effective HIV-1 vaccine available. The HIV-1 polymerase ( $p o l)$ gene is highly conserved and encodes cytotoxic T-lymphocyte (CTL) epitopes. The aim of the study was to characterise HIV-1 Pol CTL epitopes in mostly sample pairs obtained during early and chronic stages of infection.

Methods: Illumina deep sequencing was conducted for all samples while Sanger sequencing was only performed on baseline samples. Codons under immune selection pressure were assessed by computing nonsynonymous to synonymous mutation ratios using MEGA. Minority CTL epitope variants occurring at $5 \%$ were detected using lowfrequency variant tool in CLC Genomics. Los Alamos HIV database was used for mapping mutations to known HIV-1 CTL epitopes.

Results: Fifty-two participants were enrolled in the study. Their median age was 28 years (interquartile range: 24-32 years) and majority of participants (92.3\%) were female. Illumina minority variant analysis identified a significantly higher number of CTL epitopes ( $n=65)$ compared to epitopes $(n=8)$ identified through Sanger sequencing. Most of the identified epitopes mapped to reverse transcriptase (RT) and integrase (IN) regardless of sequencing method. There was a significantly higher proportion of minority variant epitopes in RT ( $n=39,60.0 \%)$ compared to IN $(n=17,26.2 \%)$ and PR $(n=$ $9,13.8 \%), p=0.002$ and $<0.0001$, respectively. However, no significant difference was observed between the proportion of minority variant epitopes in IN versus PR, $p=0.06$. Some epitopes were detected in either early or chronic HIV-1 infection whereas others were detected in both stages. Different distribution patterns of minority variant epitopes were observed in sample pairs; with some increasing or decreasing over time, while others remained constant. Some of the identified epitopes have not been previously reported for HIV-1 subtype C. There were also variants that could not be mapped to reported CTL epitopes in the Los Alamos HIV database.

Conclusion: Deep sequencing revealed many Pol CTL epitopes, including some not previously reported for HIV-1 subtype C. The findings of this study support the inclusion of RT and IN epitopes in HIV- 1 vaccine candidates as these proteins harbour many CTL epitopes.

\section{Introduction}

The HIV/AIDS pandemic has been a global crisis for four decades [1-2]. At the end of 2020, there were 37.6 million people living with HIV globally, 1.5 million new HIV-1 infections, and 690000 AIDS-related deaths [3]. South Africa has 7.9 million people living with HIV-1 (PLWH), making it the country with the highest number of infections in the world [4-5]. This highlights the need to better understand HIV-1 natural immune responses in order to bolster the efforts of developing effective HIV-1 vaccines.

During early HIV-1 infection, effective cytotoxic T-lymphocyte (CTL) immune responses play an important role in the control of viraemia, by contributing to suppression of the viral load (VL) to a set-point [6]. CTL responses target and kill virus-infected cells, via recognition of viral peptide epitopes and releasing cytokines and cytotoxic granules that facilitate cell killing [7-9]. Viral peptide epitopes are presented on the surface of infected cells by the human leukocyte antigen type I (HLA I) trans-membrane proteins encoded by $H L A-A, B$ and $C$ alleles [10-12]. The targeted epitopes undergo immune selection pressure, which leads to the emergence of viral escape mutations [13-14]. This results in evasion of the immune system, loss of immune control and ultimately progression to AIDS $[7,10]$. The majority of epitopes that play a role in the control of viraemia have been extensively studied and reported for HIV-1 Gag [15-16]. However, some studies show that HIV-1 Pol also harbours important CTL epitopes that contribute to the control of HIV-1 viraemia [17-19], hence polis included in some HIV-1 vaccine candidates [20-25]. There are limited data on the characterisation of HIV-1 Pol CTL epitopes in early and chronic HIV-1 disease stages. The aim of this study was to characterise and assess the evolution of CTL epitopes encoded by HIV-1 po/ during early and chronic stages of HIV-1 infection, using deep sequencing methods.

Page $2 / 29$ 


\section{Materials And Methods}

\section{Study population}

This was a retrospective study that used stored plasma samples that were collected from individuals in the Tshwane district of South Africa. Participants enrolled in this study had a confirmed diagnosis of early or chronic HIV-1 infection and were antiretroviral therapy (ART) naïve. They were identified in a study that screened for early HIV-1 infection in individuals who had a negative rapid test at point-of-care facilities, and diagnosis was confirmed through HIV-1 VL, antibody (enzyme-linked immunoassay), p24 antigen, Western blot and avidity testing [26]. Most of the participants were followed up, and thus samples at two time-points were available (at baseline and follow-up) for analysis.

\section{Nucleic acid extraction and amplification of HIV-1 pol}

Total nucleic acids were manually extracted from plasma samples using the QIAamp UltraSens Virus kit (Qiagen, Hilden, Germany). Samples with a VL >1000 copies/ml were extracted from a plasma input volume of $500 \mu \mathrm{l}$, which was adjusted to $1 \mathrm{ml}$ using phosphate-buffered saline (PBS). Samples with a VL $\leq 1000$ copies/ml were extracted directly from $1 \mathrm{ml}$ plasma input volume to increase nucleic acid yield. Extraction was performed according to the manufacturer's instructions except for the first centrifugation step, which was optimized to 800 relative centrifugal force (RCF) instead of the recommended 1200 RCF. This modification facilitated a more efficient dissolution of the pellet. Nucleic acids were eluted in a volume of $60 \mu \mathrm{l}$ and all the eluates were stored at $-70^{\circ} \mathrm{C}$ immediately after extraction.

The complete HIV-1 polgene was amplified in all samples using an in-house nested PCR method, employing the SuperScript ${ }^{\text {TM }}$ III One-Step RT-PCR System with Platinum ${ }^{\text {TM }}$ Taq High Fidelity DNA Polymerase (Invitrogen, Carlsbad, California, USA). Each PCR reaction was performed in a $50 \mu$ reaction, which included $5 \mu$ l of extracted RNA / DNA template, $2 \mathrm{X}$ reaction mix containing $2.4 \mathrm{mM}$ magnesium sulphate (MgSO4), $0.4 \mathrm{mM}$ of each deoxynucleotide triphosphate (dNTPs), $10 \mathrm{mM}$ sense primer, $10 \mathrm{mM}$ anti-sense primer, 5 units (U) of enzyme mix for (first round) or $1 \mathrm{U}$ of Platinum Taq polymerase (for second round), and nuclease-free water. The first-round amplicon was used as template for the second-round amplification (www.lifetechnologies.com) (Supplementary Table 1). One or two extracted HIV-1-negative controls were included in each experiment to assess potential contamination.

The following sets of primers were used for amplification of the complete pol gene: SM-F1 (outer forward) 5'-GCG GCT ACA TTA GAA GAA ATG ATG-3' (HXB2 1807-1830) and SM-R1 (outer reverse) 5'-GCC AAG TAT TGT AGA GAT CCT ACC T-3' (HXB2 5462-5488), SM-F3 (inner forward) 5'-AGA TTG TTA AAT GTT TCA ACT GTG G-3' (HXB2 1952-1976) and SM-R3 (inner reverse) 5'-CTC CTG TAT GCA AAC CCC AAT A-3' (HXB2 5245-5266). The nested primers amplified a fragment size of $3268 \mathrm{bp}$.

\section{Sanger sequencing and sequence analysis}

Sanger sequencing was performed on PCR amplicons, but only for baseline samples. Sequencing was performed commercially in six overlapping regions covering the entire pol ORF (Inqaba Biotechnical Industries, Tshwane, South Africa) (Supplementary Table 1). Sequences were edited in CLC Main Workbench 21 software (Qiagen, Hilden, Germany) and consensus sequences were generated, viewed in BioEdit 7.2.5 (https://bioedit.software.informer.com/download/) and aligned using the online version of the MAFFT program (https://mafft.cbrc.jp/alignment/server/). The HIV-1 HXB2 reference sequence (K03455.1) was used for nucleotide numbering. Phylogenetic analysis was performed on the multiple alignment and the ratio of nonsynonymous to synonymous ( $\mathrm{dN}-\mathrm{dS}$ ) mutations within the HIV-1 Pol region was computed using MEGA software (https://www.megasoftware.net/). A dN-dS ratio 5 was used to identify codons under high selection pressure and these sites were subsequently mapped to CTL epitopes documented in the Los Alamos HIV database [27].

\section{Illumina sequencing and analysis of consensus sequences}


Sequencing of PCR amplicons was performed at Inqaba Biotechnical Industries (Pretoria, South Africa), a commercial NGS service provider. Briefly paired-end libraries $(2 \times 300 \mathrm{bp})$ were prepared using the NEBNext $\circledast$ Ultra ${ }^{\mathrm{TM}}$ II DNA library prep kit for Illumina ${ }^{\circledR}$ (New England Biolabs, USA) and sequencing was performed on an Illumina MiSeq instrument (Illumina, USA).

Some samples $(n=12)$ that were viewed to have poor quality scores were sent for repeat sequencing to the National Institute for Communicable Diseases (NICD), Sequencing Core Facility, Johannesburg, South Africa. Multiplexed pairedend libraries $\left(2 \times 300\right.$ bp) were prepared using the Nextera ${ }^{T M}$ XT DNA Library Sample Preparation kit (Illumina Inc., California, United States) according to the manufacturer's instructions and sequencing was carried out on an Illumina MiSeq instrument (Illumina Inc., California, United States)

Illumina sequencing data was analysed in the PASeq program (https://paseq.org/) using the feature that excludes APOBEC-induced hypermutations, and consensus sequences were generated. The quality of the Illumina reads was assessed in PASeq and CLC Genomics Workbench 21 (Qiagen, Hilden, Germany). PASeq-generated Illumina consensus sequences were viewed in BioEdit 7.2.5 software and aligned to HIV-1 reference sequences obtained from the GenBank database, in the MAFFT program available online. Sanger and Illumina consensus sequences obtained from baseline samples were compared through phylogenetic analysis in MEGA software and were observed to correctly cluster together (Supplementary Figure 1).

\section{Analysis of Illumina sequencing reads for minority variants}

Deep sequencing reads were mapped to an HIV-1 subtype C reference (AY162225.1) in CLC Genomics. Minority variants were analysed using a low-frequency variant detection tool in CLC Genomics, setting the cut-off for significance at $1 \%$ and the minimum frequency for variants at $5 \%$. Minority variants were assessed in all participant samples and only nonsynonymous variants were mapped to HIV-1 CTL epitopes in the Los Alamos HIV database, to identify the epitope they fall within. Thus, in this study, minority variant epitopes were defined as epitopes existing at proportions above $5 \%$ but less than $20 \%$. The Los Alamos HIV database was also used to predict human leukocyte antigen (HLA) allotypes that may be involved in presenting the identified epitopes to CTLs. Evolution within Pol CTL epitopes was assessed by comparing the proportion of minority variants between baseline and follow-up samples, and in early and chronic HIV-1 disease stages.

\section{Data analysis}

Descriptive statistics was used to present median values and interquartile range (IQR) for age, HIV-1 VL and sequencing depth. Fisher's exact test was used to assess if there was an association between the distribution of mutations and HIV-1 disease stage for epitopes identified through Sanger sequencing. Two sample t-test was used for comparing the proportions of minority variant epitopes among the different regions of the Pol protein. A p-value of $\leq 0.05$ was considered statistically significant. All statistical tests were performed on the STATA 16.0 software package (StataCorp LP, College Station, TX, USA). The statistical analyses of dN-dS ratios were computed on the MEGA programme using the HyPhy test for selection. Due to the small sample size, codons with dN-dS ratios of $\geq 5$ were considered for assessment of epitopes under immune selection pressure. GraphPad Prism v.9.1.2 (GraphPad Software, San Diego, California, USA) was used to prepare graphs for the frequently recognised minority variant epitopes among the different regions of the Pol protein, and also for showing the dynamics of these epitopes in sample pairs obtained during early and chronic HIV-1 infection stages.

\section{Results}

\section{Demographics}

This study enrolled 52 participants with HIV-1 infection, 34 of whom had paired plasma samples. Their median age was 28 years (IQR: 24 - 32 years), and majority were females (92.3\%). There were 15 participants (28.9\%) with early HIV-1 
infection and 37 (71.1\%) with chronic HIV-1 infection. The median HIV-1 VL at baseline was $2.8 \times$ copies/mL (IQR: $8.6 \mathrm{x}$ $-9.1 \times$ copies $/ \mathrm{mL}$ ). The median interval between baseline and follow-up sampling was 4 weeks (IQR: $3-8$ weeks) (Table 1).

\section{Amplification of HIV-1 pol and phylogenetic analysis}

The complete HIV-1 polgene was successfully amplified in all project samples using the in-house nested PCR method. Phylogenetic analysis of Illumina consensus sequences showed that most study sequences clustered with HIV-1 subtype C strains. All baseline and follow-up sequences for each participant correctly clustered together (Figure 1), showing accurate amplification and sequencing of viral genes from the same participant.

\section{Pol CTL epitopes based on Sanger consensus sequences}

Eight CTL epitopes, with amino acid residues under high selection pressure, were identified. The majority of the identified epitopes were located within RT. The distribution of escape mutations was comparable between early and chronic HIV-1 disease stages (Table 2). However, these escape mutations were identified mostly in participants with chronic HIV-1 infection (Supplementary Table 2). One or more escape mutations were observed in each epitope. Two other codons were identified to be under high selection pressure but could not be mapped to the reported CTL epitopes in the Los Alamos HIV database (Table 2).

\section{Pol CTL epitopes based on analysis of minority variants}

The median sequencing depth (for baseline and follow-up) was 23052X (IQR: 13011 - 49753X) (Table 1). Minority variant analysis identified 65 frequently targeted Pol CTL epitopes. There was a significantly higher proportion of epitopes in RT $(n=39,60.0 \%)$ compared to IN $(n=17,26.2 \%)$ and PR $(n=9,13.8 \%), p=0.002$ and $<0.0001$, respectively. However, no significant difference was observed between the proportion of minority epitopes in IN versus $P R, p=0.06$. The majority of these epitopes were identified in participants with chronic HIV-1 infection compared to those with early HIV-1 infection. Some epitopes were only identified in either early or chronic HIV-1 infection, whereas others were identified in both stages of disease (Figure 2). Different distribution patterns of minority variant epitopes were observed. Some variant epitopes increased or decreased between baseline and follow-up, while others remained constant between these two time-points (Figure 3, Supplementary Table 3). There were minority variants (2 in early and 26 in chronic HIV-1 infection) that could not be mapped to the reported CTL epitopes in the Los Alamos HIV database (Supplementary Table 3).

\section{Pol CTL epitopes and predicted HLA class I presentation}

HLA class I allotypes that possibly present the identified epitopes were predicted from the Los Alamos HIV database. Some participants recognised more epitopes than others. This was observed for participants 8047 and 6743 who each recognised seven epitopes during early HIV-1 infection. The most commonly targeted epitope during early HIV-1 infection was SAAVKAACW (IN 123-131), located in IN, and possibly presented by HLA-B*58:01 [27]. The same trend was noticed in chronic HIV-1 infection where the most frequently targeted epitope, MASDFNLPPIV (IN 22-31), was also located in IN and possibly presented by HLA-A*02 [27]. Some of the frequently targeted epitopes identified in this study have never been reported for HIV-1 subtype C. HLA class I allotypes that possibly present the identified epitopes in this study have been reported previously in the South African population [11-12,28-32]. Some epitopes were predicted to be recognised by multiple HLA class I allotypes. There were also frequently recognised epitopes that seemed to have similar HLA class I restriction such as ALQDSGLEV (RT 485-494) and RAMASDFNL (IN 20-28) in early HIV-1 infection (Table 3).

\section{Discussion}


To our knowledge, this is the first study to assess the evolution of HIV-1 Pol CTL epitopes in samples obtained during early and chronic disease stages in a setting where HIV-1 subtype $\mathrm{C}$ is predominant. We identified epitopes within all three regions of Pol, unlike previous studies that have only characterised epitopes within RT and PR $[16,29,33]$. This highlights the advantage of using a PCR method that amplifies the complete $\mathrm{pol}$ gene. Baseline and follow-up sequences for each participant correctly clustered together, indicating accurate amplification and sequencing of viral genes belonging to the same participant. It was expected that the majority of sequences would cluster with HIV-1 subtype $\mathrm{C}$ as this is the most common subtype in the southern African region [34-35]. A small number of non-subtype $C$ strains were detected, which could have been introduced through migration, and this has also been reported in previous South African studies [36-37].

Many epitopes were identified through the analysis of minority variants obtained by deep sequencing compared to majority variants obtained by Sanger sequencing. This shows the advantage of using deep sequencing for characterisation of Pol CTL epitopes as this method can detect variants that exist below $20 \%$ of the total virus population, which are not readily detected by Sanger sequencing [38-39]. Some identified minority variant epitopes have never been reported for HIV-1 subtype $\mathrm{C}$ and were possibly missed by previous studies that employed Sanger sequencing. The use of Sanger sequencing in most studies has most likely underestimated the presence of CTL epitopes in Pol. Other studies have also shown increased detection of CTL epitopes when using next-generation sequencing (NGS) methods [40-41]. This shows an advantage in the use of NGS for characterising HIV-1 CTL epitopes in future research studies.

In this study, CTL epitopes were identified in all regions of Pol, but mostly in RT and IN. Some of these epitopes such as GKKAIGTVL (PR 68-76) and IAMESIVIW (RT 375-383) (Table 3) have been previously reported to induce CTL responses [42-43]. These data indicate that all three regions of Pol are immunogenic and may play a role in the control of viraemia and the establishment of a viral set-point during early HIV-1 infection, in agreement with previous studies that assessed CTL responses against the HIV-1 proteome [42-44]. In a study that assessed CTL responses during acute HIV-1 infection, Kim et al showed that the larger proportion of targeted epitopes were within Pol as compared to other regions of the HIV-1 proteome, and some of these epitopes stimulated strong CTL responses [42]. Ojwach et a/ reported that CTL responses towards epitopes in RT and IN during acute and chronic HIV-1 infection induced mutations that decreased viral replicative fitness, indicating that RT and IN harbour crucial CTL epitopes [45]. Fewer epitopes were identified in PR especially during early HIV-1 infection and this could indicate that this protein harbours more subdominant CTL epitopes that are mostly recognised later during the course of infection [46]. Thus, PR might have a limited role in control of viraemia during early HIV-1 infection. CTL epitopes encoded by po/ have also been reported to play a role in the control of viraemia in long-term non-progressors (LTNPs) and elite controllers (ECs) [47-48].

HLA class I allotypes play an important role in the control of HIV-1 viraemia [29]. Several HLA class I alleles that encode allotypes predicted to present epitopes identified in this study are known to be present in the South African population, including HLA-B*58:01 and HLA-A*02 that present SAAVKAACW (IN 123-131) and MASDFNLPPIV (IN 22-31), respectively $[28,30,49]$. Past gene association studies showed that alleles within the $H L A-B$ group correlate with greater viral control than alleles in the $H L A-A$ and $H L A-C$ groups [28-29,50]. Payne et al found that $H L A-B \star 58: 01$ was associated with slower HIV-1 disease progression and was protective against HIV-1 infection [51], which could explain why some participants such as 8047 and 6743 recognised more epitopes, as they also recognised an epitope reported to be presented by HLA$B \star 58: 01$. A hierarchy in epitope presentation may be an explanation for recognition of more epitopes during chronic HIV-1 infection. Immunodominant epitopes could be preferentially presented earlier during the course of infection, followed by presentation of subdominant epitopes later [52]. Immunodominant epitopes are often located in variable domains whereas subdominant epitopes usually map to more conserved regions of the HIV-1 proteome [18,53]. The HIV-1 pol gene is more conserved than gag and env [54] and therefore harbours more subdominant epitopes [18]. Examples of subdominant responses being more effective in controlling viraemia have been shown in past studies [55-56].

The evolution of Pol CTL epitopes was monitored by assessing minority variants in sample pairs. Minority variant epitopes that increased in proportion from baseline to follow-up may have replaced the wild-type epitopes over time and 
facilitated immune escape [57]. Fitness cost is the likely explanation for minority variant epitopes that decreased in proportion over time, and these may have been out-competed by new variants [57]. The proportion of some minority variant epitopes remained constant between the two time-points, and these could also represent variants that do not replicate efficiently and are hence maintained at lower levels within the HIV-1 quasispecies [40,57]. Some variant sites were located outside of reported epitopes (Supplementary Table 3), and these may represent new unreported epitopes or could highlight important adjacent sites that may affect epitope processing and presentation [13,58]. Viral evolution was also assessed by comparing sequences from early and chronic HIV-1 stages. Data from this study showed that evolution within CTL epitopes began quite early following infection, as epitopes with escape mutations were detected in participants who had early HIV-1 infection [59]. Many epitopes with escape mutations were detected in participants in the chronic HIV-1 stage, indicating that viral evolution of HIV-1 results from immune selection pressure that occurs throughout the course of infection and diverse viral populations evolve that constantly evade immune responses $[57,60]$.

All three expressed proteins (PR, RT and IN) of Pol harbour CTL epitopes and this highlights the importance of including $\mathrm{pol}$ in the design of a vaccine candidate [2,20]. Some researchers have included RT and IN in the design of HIV-1 vaccines [22-23,53]; this is supported by the findings of our study as the majority of epitopes mapped to these two proteins. Conserved epitopes have been shown to provide cross-clade protection against HIV-1 infection [2,18]. Some of the conserved Pol epitopes such as IETVEPVKL (RT 5-12) and SVPLDEGFRK (RT 117-126) (Table 3), that were previously observed in a study that looked at using a vaccine candidate with conserved immunogens were also identified in our study [18]. The immune responses directed towards epitopes in conserved regions are usually subdominant but may provide protection against multiple HIV-1 subtypes [17,53]. Many studies that included Pol epitopes in vaccine candidates showed stimulation of effective CTL responses [18,56,61-62]. Ahmed et al, showed control of HIV-1 replication in vitro through stimulation of Pol CTL responses by a vaccine that contained subdominant epitopes [56].

Limitations of this study include the small sample size and fewer participants with early HIV-1 infection. The duration of infection in participants with chronic HIV-1 infection was not known. HIV-1 VL was not measured in the participants at follow-up, therefore no correlation between $V L$ and the number of minority variant epitopes detected could be made. Functional CTL responses against identified epitopes were not determined and genomic DNA samples were unavailable to conduct HLA class I genotyping. Longitudinal samples were only obtained at two time-points for most of the participants at a median interval of 4 weeks and this might not be sufficient for assessing viral evolution.

\section{Conclusions}

Deep sequencing revealed many HIV-1 Pol CTL epitopes, including some which have never been reported for HIV-1 subtype C. Immune selection pressure on Pol CTL epitopes was observed during early HIV-1 infection highlighting the possibility that these epitopes might contribute to the control of viraemia and the establishment of a VL set-point. Variable patterns of distribution of epitopes in sample pairs reflect the ongoing generation of escape mutants capable of evading the immune responses throughout the course of infection. The findings of this study support the inclusion of RT and IN in potential HIV-1 vaccine candidates, as these regions harbour the majority of CTL epitopes. Variants that could not be mapped to known epitopes in the Los Alamos HIV database might represent new unreported epitopes. Future research, using deep sequencing, is needed for better characterisation of Pol epitopes as this protein contains highly conserved epitopes that have the potential to provide HIV-1 cross-clade protection.

\section{Abbreviations}

HIV-1: Human immunodeficiency virus type 1

PLWH: People living with HIV 
CTL: Cytotoxic T-lymphocyte

VL: Viral load

HLA I: Human leukocyte antigen type 1

ART: Antiretroviral therapy

RCF: Replicative centrifugal force

RT-PCR: Reverse transcriptase polymerase chain reaction

RNA: Ribonucleic acid

DNA: Deoxyribonucleic acid

dNTPs: Deoxynucleotide triphosphate

ORF: Open reading frame

NGS: Next generation sequencing

IQR: Interquartile range

Gag: group-specific antigen

Pol: Polymerase

Env: Envelope

PR: Protease

RT: Reverse transcriptase

IN: Integrase

LTNP: Long-term non-progressors

EC: Elite controllers

\section{Declarations}

\section{Funding}

PN was funded by the National Research Foundation (NRF) and Poliomyelitis Research Foundation (PRF grant number: 20/22).

SHM received funding from Discovery Foundation, National Health Laboratory Service Research Trust (NHLS-RT), South African Medical Research Council Self-Initiated Research (MRC-SIR), and University of Pretoria Faculty of Health Sciences Research Committee.

CTT receives funding through the South African Research Chairs Initiative of the Department of Science and Innovation and National Research Foundation of South Africa (84177). 
TCQ and ADR - The Division of Intramural Research, NIAID, NIH.

\section{Author contributions}

Conceptualization: SHM.

Methodology: PN, SHM.

Funding acquisition: PN, SHM.

Investigation: PN, SHM.

Supervision: SHM, CTT.

Project administration: PN, SHM.

Data analysis: PN, SHM, CTT, TCQ, SL, AR, Al.

Writing - original draft: PN.

Writing - review \& editing: PN, SHM, CTT, TCQ, SL, AR, AI.

\section{Competing interest}

The authors declared no competing interest.

\section{Ethics approval and consent to participate}

Ethics approval was obtained for this study from the Faculty of Health Sciences Research Ethics Committee, University of Pretoria, South Africa: Reference number 282/2020. Written consent was obtained from all participants in the parent study (Ethics reference: 295/2015) [26].

\section{Consent for publication}

Not applicable

\section{Availability of data and materials}

All data generated or analysed during this study are included in this manuscript and its supplementary information files.

\section{Acknowledgements}

We thank Prof. Marietjie Venter and Dr. Adriano Mendes for granting us access to their CLC Genomics software program.

\section{References}

1. Greene WC. A history of AIDS: Looking back to see ahead. Eur J Immunol. 2008; doi:10.1002/eji.200737441

2. Fauci AS, Marston HD. Ending AIDS-is an HIV vaccine necessary? N Engl J Med. 2014; 370:495-8. doi:10.1056/NEJMp1313771

3. UNAIDS [Internet]. Fact Sheet 2021 - Preliminary epidemiological estimates. 2021 [accessed July 2021]. Available from: https://www.unaids.org/sites/default/files/media_asset/UNAIDS_FactSheet_en.pdf. 
4. UNAIDS [Internet]. Global 2019 HIV/AIDS Statistics. 2020 [accessed May 2021]. Available from: https://www.unaids.org/en/resources/documents/2020/unaids-data.

5. HSRC. The fifth South African national HIV prevalence, incidence, behaviour and communication survey, 2017: HIV impact assessment summary report. HSRC Press Cape Town; 2018.

6. Tiemessen CT, Martinson N. Elite controllers: understanding natural suppressive control of HIV-1 infection. CMEJ. 2012; 30:282-5.

7. Gulzar N, Copeland KF. CD8+ T-cells: function and response to HIV infection. Curr HIV Res. 2004; 2:23-37. doi:10.2174/1570162043485077

8. Collins DR, Gaiha GD, Walker BD. CD8+ T cells in HIV control, cure and prevention. Nature Reviews Immunology. 2020; 20:471-82. doi:10.1038/s41577-020-0274-9

9. Perdomo-Celis F, Taborda NA, Rugeles MT. CD8(+) T-Cell Response to HIV infection in the era of antiretroviral therapy. Front Immunol. 2019; 10:1896-. doi:10.3389/fimmu.2019.01896

10. McMichael AJ, Borrow P, Tomaras GD, Goonetilleke N, Haynes BF. The immune response during acute HIV-1 infection: clues for vaccine development. Nat Rev Immunol. 2010; 10:11-23. doi:10.1038/nri2674

11. Tshabalala M, Mellet J, Pepper MS. Human Leukocyte Antigen diversity: A Southern African perspective. J Immunol Res. 2015; 2015:746151. doi:10.1155/2015/746151

12. Hammond M, Anley D, editors. Tamil from Natal province South Africa. 13th International Histocompatibility Workshop; 2006; Seattle. Washington, USA: International Histocompatibility Working Group Press.

13. Allen TM, Altfeld M, Yu XG, O'Sullivan KM, Lichterfeld M, Le Gall S., et al. Selection, transmission, and reversion of an antigen-processing cytotoxic T-lymphocyte escape mutation in human immunodeficiency virus type 1 infection. J Virol. 2004; 78:7069-78. doi:10.1128/jvi.78.13.7069-7078.2004

14. Draenert R, Le Gall S, Pfafferott KJ, Leslie AJ, Chetty P, Brander C., et al. Immune selection for altered antigen processing leads to cytotoxic T lymphocyte escape in chronic HIV-1 infection. J Exp Med. 2004; 199:905-15. doi:10.1084/jem.20031982

15. Kiepiela P, Ngumbela K, Thobakgale C, Ramduth D, Honeyborne I, Moodley E., et al. CD8+ T-cell responses to different HIV proteins have discordant associations with viral load. Nat Med. 2007; 13:46-53. doi:10.1038/nm1520

16. Masemola A, Mashishi T, Khoury G, Mohube P, Mokgotho P, Vardas E., et al. Hierarchical targeting of subtype $C$ human immunodeficiency virus type 1 proteins by CD8+ T cells: correlation with viral load. J Virol. 2004; 78(7):3233-43. doi:10.1128/jvi.78.7.3233-3243.2004

17. Kunwar P, Hawkins N, Dinges WL, Liu Y, Gabriel EE, Swan DA., et al. Superior control of HIV-1 replication by CD8+ T cells targeting conserved epitopes: implications for HIV vaccine design. PLoS One. 2013; 8:e64405.

doi:10.1371/journal.pone.0064405

18. Borthwick N, Lin Z, Akahoshi T, Llano A, Silva-Arrieta S, Ahmed T., et al. Novel, in-natural-infection subdominant HIV-1 CD8+ T-cell epitopes revealed in human recipients of conserved-region T-cell vaccines. PloS One. 2017; 12:e0176418. doi:10.1371/journal.pone.0176418 
19. Acevedo-Sáenz L, Ochoa R, Rugeles MT, Olaya-García P, Velilla-Hernández PA, Diaz FJ. Selection pressure in CD8+ Tcell epitopes in the pol gene of HIV-1 infected individuals in Colombia. A bioinformatic approach. Viruses. 2015; 7:131331. doi:10.3390/v7031313

20. Hsu DC, O'Connell RJ. Progress in HIV vaccine development. Hum Vaccin Immunother. 2017; 13:1018-30. doi:10.1080/21645515.2016.1276138

21. Harmon TM, Fisher KA, McGlynn MG, Stover J, Warren MJ, Teng Y., et al. Exploring the Potential Health Impact and Cost-Effectiveness of AIDS Vaccine within a Comprehensive HIV/AIDS Response in Low- and Middle-Income Countries. PLoS One. 2016; 11:e0146387. doi:10.1371/journal.pone.0146387

22. Buchbinder SP, Mehrotra DV, Duerr A, Fitzgerald DW, Mogg R, Li D., et al. Efficacy assessment of a cell-mediated immunity HIV-1 vaccine (the Step Study): a double-blind, randomised, placebo-controlled, test-of-concept trial. Lancet. 2008; 372:1881-93. doi:10.1016/s0140-6736(08)61591-3

23. Gray GE, Allen M, Moodie Z, Churchyard G, Bekker LG, Nchabeleng M., et al. Safety and efficacy of the HVTN 503/Phambili study of a clade-B-based HIV-1 vaccine in South Africa: a double-blind, randomised, placebo-controlled testof-concept phase 2b study. Lancet Infect Dis. 2011; 11:507-15. doi:10.1016/s1473-3099(11)70098-6

24. Priddy FH, Brown D, Kublin J, Monahan K, Wright DP, Lalezari J., et al. Safety and immunogenicity of a replicationincompetent adenovirus type 5 HIV-1 clade B gag/pol/nef vaccine in healthy adults. Clin Infect Dis. 2008; 46:1769-81. doi:10.1086/587993

25. Stephenson KE, Wagh K, Korber B, Barouch DH. Vaccines and broadly neutralizing antibodies for HIV-1 prevention. Annu Rev Immunol. 2020; 38:673-703. doi:10.1146/annurev-immunol-080219-023629

26. Mayaphi SH. Detection and characterisation of primary (acute and early) HIV-1 infections in an HIV hyper-endemic area [Thesis]. Pretoria: University of Pretoria; 2018.

27. LANL [Internet]. HIV molecular immunology database. Los Alamos National Laboratory (NIH); 2021. Available from: https://www.hiv.lanl.gov/content/immunology/tables/ctl_summary.html.

28. Leslie A, Matthews PC, Listgarten J, Carlson JM, Kadie C, Ndung'u T., et al. Additive contribution of HLA class I alleles in the immune control of HIV-1 infection. J Virol. 2010; 84:9879-88. doi:10.1128/JVI.00320-10

29. Carlson JM, Listgarten J, Pfeifer N, Tan V, Kadie C, Walker BD., et al. Widespread impact of HLA restriction on immune control and escape pathways of HIV-1. J Virol. 2012; 86:5230-43. doi:10.1128/JVI.06728-11

30. Loubser S, Paximadis M, Gentle NL, Puren A, Tiemessen CT. Human leukocyte antigen class I (A, B, C) and class II (DPB1, DQB1, DRB1) allele and haplotype variation in Black South African individuals. Hum Immunol. 2020; 81:6-7. doi:10.1016/j.humimm.2019.12.003

31. Paximadis M, Mathebula TY, Gentle NL, Vardas E, Colvin M, Gray CM., et al. Human Leukocyte Antigen class I (A, B, C) and II (DRB1) diversity in the black and Caucasian South African population. Hum Immunol. 2012; 73:80-92. doi:10.1016/j.humimm.2011.10.013

32. Coetzee V, Barrett L, Greeff JM, Henzi SP, Perrett DI, Wadee AA. Common HLA alleles associated with health, but not with facial attractiveness. PLoS One. 2007; 2:e640. doi:10.1371/journal.pone.0000640

33. Brumme ZL, Brumme CJ, Carlson J, Streeck H, John M, Eichbaum Q., et al. Marked epitope-and allele-specific differences in rates of mutation in human immunodeficiency type 1 (HIV-1) gag, pol, and nef cytotoxic T-lymphocyte

Page $11 / 29$ 
epitopes in acute/early HIV-1 infection. J Virol. 2008; 82:9216-27. doi:10.1128/JVI.01041-08

34. Bbosa N, Kaleebu P, Ssemwanga D. HIV subtype diversity worldwide. Curr Opin HIV AIDS. 2019; 14:153-60. doi:10.1097/coh.0000000000000534

35. Buonaguro L, Tornesello M, Buonaguro F. Human immunodeficiency virus type 1 subtype distribution in the worldwide epidemic: pathogenetic and therapeutic implications. J Virol. 2007; 81:10209-19. doi:10.1128/JVI.00872-07

36. Jacobs GB, Wilkinson E, Isaacs S, Spies G, De Oliveira T, Seedat S., et al. HIV-1 subtypes B and C unique recombinant forms (URFs) and transmitted drug resistance identified in the Western Cape Province, South Africa. PloS One. 2014; 9:e90845. doi:10.1371/journal.pone.0090845

37. Heipertz Jr RA, Ayemoba O, Sanders-Buell E, Poltavee K, Pham P, Kijak GH., et al. Significant contribution of subtype G to HIV-1 genetic complexity in Nigeria identified by a newly developed subtyping assay specific for subtype $G$ and CRF02_AG. Medicine. 2016; 95(32)

38. Kumar KR, Cowley MJ, Davis RL. Next-Generation Sequencing and Emerging Technologies. Semin Thromb Hemost. 2019; 45(7):661-73. doi:10.1055/s-0039-1688446

39. Pareek CS, Smoczynski R, Tretyn A. Sequencing technologies and genome sequencing. J Appl Genet. 2011; 52(4):41335. doi:10.1007/s13353-011-0057-x

40. Caetano DG, Côrtes FH, Bello G, Teixeira SLM, Hoagland B, Grinsztejn B., et al. Next-generation sequencing analyses of the emergence and maintenance of mutations in CTL epitopes in HIV controllers with differential viremia control. BMC Retrovirol. 2018; 15(1):62. doi:10.1186/s12977-018-0444-z

41. Tumiotto C, Riviere L, Bellecave P, Recordon-Pinson P, Vilain-Parce A, Guidicelli GL., et al. Sanger and Next-Generation Sequencing data for characterization of CTL epitopes in archived HIV-1 proviral DNA. PLoS One. 2017; $12(9)$ :e0185211. doi:10.1371/journal.pone.0185211

42. Kim J, De La Cruz J, Lam K, Ng H, Daar ES, Balamurugan A., et al. CD8(+) Cytotoxic T Lymphocyte Responses and Viral Epitope Escape in Acute HIV-1 Infection. Viral Immunol. 2018; 31(7):525-36. doi:10.1089/vim.2018.0040

43. Li F, Finnefrock AC, Dubey SA, Korber BT, Szinger J, Cole S., et al. Mapping HIV-1 vaccine induced T-cell responses: bias towards less-conserved regions and potential impact on vaccine efficacy in the Step study. PloS One. 2011; 6:e20479. doi:10.1371/journal.pone.0020479

44. Goonetilleke N, Liu MK, Salazar-Gonzalez JF, Ferrari G, Giorgi E, Ganusov VV., et al. The first T cell response to transmitted/founder virus contributes to the control of acute viremia in HIV-1 infection. J Exp Med. 2009; 206:1253-72. doi:10.1084/jem.20090365

45. Ojwach DBA, MacMillan D, Reddy T, Novitsky V, Brumme ZL, Brockman MA., et al. Pol-Driven Replicative Capacity Impacts Disease Progression in HIV-1 Subtype C Infection. J Virol. 2018; 92(19) doi:10.1128/jvi.00811-18

46. Rhee SY, Sankaran K, Varghese V, Winters MA, Hurt CB, Eron JJ., et al. HIV-1 Protease, Reverse Transcriptase, and Integrase Variation. J Virol. 2016; 90(13):6058-70. doi:10.1128/jvi.00495-16

47. Miura T, Brumme ZL, Brockman MA, Rosato P, Sela J, Brumme CJ., et al. Impaired replication capacity of acute/early viruses in persons who become HIV controllers. J Virol. 2010; 84(15):7581-91. doi:10.1128/jvi.00286-10 
48. Pernas M, Casado C, Arcones C, Llano A, Sánchez-Merino V, Mothe B., et al. Low-replicating viruses and strong antiviral immune response associated with prolonged disease control in a superinfected HIV-1 LTNP elite controller. PLoS One. 2012; 7(2):e31928. doi:10.1371/journal.pone.0031928

49. Mellet J, Tshabalala M, Agbedare O, Meyer P, Gray CM, Pepper MS. Human leukocyte antigen (HLA) diversity and clinical applications in South Africa. S Afr Med J. 2019; 109:29-34. doi:10.7196/SAMJ.2019.v109i8b.13825

50. Goulder PJ, Walker BD. HIV and HLA class I: an evolving relationship. Immunity. 2012; 37:426-40. doi:10.1016/j.immuni.2012.09.005

51. Payne R, Muenchhoff M, Mann J, Roberts HE, Matthews P, Adland E., et al. Impact of HLA-driven HIV adaptation on virulence in populations of high HIV seroprevalence. Proc Natl Acad Sci U S A. 2014; 111(50):E5393-400. doi:10.1073/pnas.1413339111

52. Adland E, Hill M, Lavandier N, Csala A, Edwards A, Chen F., et al. Differential Immunodominance Hierarchy of CD8(+) TCell Responses in HLA-B*27:05- and -B*27:02-Mediated Control of HIV-1 Infection. J Virol. 2018; 92 doi:10.1128/jvi.0168517

53. Liu Y, McNevin J, Rolland M, Zhao H, Deng W, Maenza J., et al. Conserved HIV-1 epitopes continuously elicit subdominant cytotoxic T-lymphocyte responses. J Infect Dis. 2009; 200(12):1825-33. doi:10.1086/648401

54. Tebit DM, Arts EJ. Tracking a century of global expansion and evolution of HIV to drive understanding and to combat disease. Lancet Infect Dis. 2011;11:45-56. doi:10.1016/S1473-3099(10)70186-9

55. Friedrich TC, Valentine LE, Yant LJ, Rakasz EG, Piaskowski SM, Furlott JR., et al. Subdominant CD8+ T-cell responses are involved in durable control of AIDS virus replication. J Virol. 2007; 81(7):3465-76. doi:10.1128/jvi.02392-06

56. Ahmed T, Borthwick NJ, Gilmour J, Hayes P, Dorrell L, Hanke T. Control of HIV-1 replication in vitro by vaccine-induced human CD8(+) T cells through conserved subdominant Pol epitopes. Vaccine. 2016; 34(9):1215-24.

doi:10.1016/j.vaccine.2015.12.021

57. Liu Y, McNevin J, Zhao H, Tebit DM, Troyer RM, McSweyn M., et al. Evolution of human immunodeficiency virus type 1 cytotoxic T-lymphocyte epitopes: fitness-balanced escape. J Virol. 2007; 81:12179-88. doi:10.1128/jvi.01277-07

58. Yokomaku Y, Miura H, Tomiyama H, Kawana-Tachikawa A, Takiguchi M, Kojima A., et al. Impaired processing and presentation of cytotoxic-T-lymphocyte $(C T L)$ epitopes are major escape mechanisms from CTL immune pressure in human immunodeficiency virus type 1 infection. J Virol. 2004; 78(3):1324-32. doi:10.1128/jvi.78.3.1324-1332.2004

59. Sun J, Zhao Y, Peng Y, Han Z, Liu G, Qin L., et al. Multiple T-cell responses are associated with better control of acute HIV-1 infection: An observational study. Medicine 2016; 95:e4429. doi:10.1097/md.0000000000004429

60. Koibuchi T, Allen TM, Lichterfeld M, Mui SK, O'Sullivan KM, Trocha A., et al. Limited sequence evolution within persistently targeted CD8 epitopes in chronic human immunodeficiency virus type 1 infection. J Virol. 2005; 79(13):817181. doi:10.1128/jvi.79.13.8171-8181.2005

61. Mohamed YS, Borthwick NJ, Moyo N, Murakoshi H, Akahoshi T, Siliquini F., et al. Specificity of CD8+ T-Cell responses following vaccination with conserved regions of HIV-1 in Nairobi, Kenya. Vaccine. 2020; 8:260.

doi:10.3390/vaccines8020260

62. Zou C, Murakoshi H, Kuse N, Akahoshi T, Chikata T, Gatanaga H., et al. Effective Suppression of HIV-1 Replication by Cytotoxic T Lymphocytes Specific for Pol Epitopes in Conserved Mosaic Vaccine Immunogens. J Virol. 2019; 93(7)

Page $13 / 29$ 
doi:10.1128/jvi.02142-18

\section{Tables}

Table 1: Study participants' demographic data 
Baseline sequencing

$\begin{array}{llllllll}\text { Sample } & \text { Sex } & \begin{array}{l}\text { Age } \\ \text { (years) }\end{array} & \begin{array}{l}\text { HIV } \\ \text { Stage }\end{array} & \begin{array}{l}\text { HIV } \\ \text { VL }\end{array} & \begin{array}{l}\text { Total } \\ \text { reads }\end{array} & \begin{array}{l}\text { HIV } \\ \text { reads }\end{array} & \begin{array}{l}\text { Sequencing } \\ \text { depth }(x)\end{array}\end{array}$

261

M 33

$33-1$

(261

$2504 \quad F \quad 24$

$\begin{array}{lllll}8.4 & 415 & 198 & 17408 & \text { No FU }\end{array}$

E

$3469 \quad F \quad 20$

E

$\begin{array}{llll}3.7 & 396 & 288 & 25452 \\ \times & 640 & 841 & \end{array}$

$\begin{array}{llll}3.3 & 79 & 38 & 3139 \\ \times & 948 & 927 & \end{array}$

$5041 \quad M \quad 23$

E

2.2146

$6512 \quad F \quad 23$

$6727 \quad F \quad 28$

3

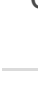

$6638 \quad F \quad 28 \quad E$

$6582 \quad F \quad 24 \quad E \quad x$

$9498 \quad \mathrm{~F} \quad 34 \quad \mathrm{E}$

\begin{tabular}{|c|c|c|c|c|c|c|c|c|c|c|c|}
\hline 9049 & $\mathrm{~F}$ & 20 & $E$ & $\begin{array}{l}1.6 \\
x\end{array}$ & $\begin{array}{l}363 \\
168\end{array}$ & $\begin{array}{l}226 \\
752\end{array}$ & 19829 & 3 & $\begin{array}{l}1 \\
724 \\
070\end{array}$ & $\begin{array}{l}1 \\
406 \\
644\end{array}$ & 65497 \\
\hline
\end{tabular}

\begin{tabular}{|c|c|c|c|c|c|c|c|}
\hline 8575 & $\mathrm{~F}$ & 27 & $E$ & $\begin{array}{l}9.3 \\
x\end{array}$ & $\begin{array}{l}355 \\
040\end{array}$ & $\begin{array}{l}238 \\
087\end{array}$ & 21126 \\
\hline
\end{tabular}

\begin{tabular}{|c|c|c|c|c|c|c|c|}
\hline 8047 & $M$ & 31 & $E$ & $\begin{array}{l}1.2 \\
x\end{array}$ & $\begin{array}{l}386 \\
426\end{array}$ & $\begin{array}{l}308 \\
249\end{array}$ & 28180 \\
\hline
\end{tabular}

\begin{tabular}{|c|c|c|c|c|c|}
\hline 7084 & $F$ & 28 & $E$ & $\begin{array}{l}3.3 \\
x\end{array}$ & $\begin{array}{l}199 \\
022\end{array}$ \\
\hline
\end{tabular}

\begin{tabular}{llllllllllll}
6743 & $F$ & 26 & $E$ & 2.7 & 87 & 43 & 3928 & 7 & 223 & 149 & 78503 \\
& & & $x$ & 982 & 575 & & & 468 & 257 & \\
\hline
\end{tabular}

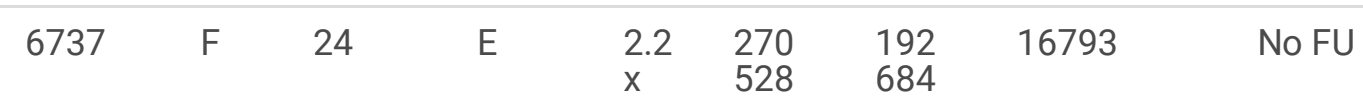

\begin{tabular}{|c|c|c|c|c|c|c|c|c|c|c|c|}
\hline 639 & $\mathrm{~F}$ & 30 & C & $\begin{array}{l}6.5 \\
x\end{array}$ & $\begin{array}{l}851 \\
104\end{array}$ & $\begin{array}{l}651 \\
917\end{array}$ & 60785 & 7 & $\begin{array}{l}408 \\
144\end{array}$ & $\begin{array}{l}293 \\
996\end{array}$ & 25994 \\
\hline 641 & $\mathrm{~F}$ & 30 & C & $\begin{array}{l}7.0 \\
x\end{array}$ & $\begin{array}{l}1 \\
334 \\
058\end{array}$ & $\begin{array}{l}969 \\
199\end{array}$ & 45128 & 4 & $\begin{array}{l}153 \\
448\end{array}$ & $\begin{array}{l}113 \\
391\end{array}$ & 10062 \\
\hline 843 & $\mathrm{~F}$ & 21 & C & $\begin{array}{l}2.9 \\
x\end{array}$ & $\begin{array}{l}328 \\
480\end{array}$ & $\begin{array}{l}278 \\
706\end{array}$ & 16615 & 5 & $\begin{array}{l}1 \\
458 \\
950\end{array}$ & $\begin{array}{l}1 \\
250 \\
697\end{array}$ & 58236 \\
\hline
\end{tabular}

\begin{tabular}{|c|c|c|c|c|c|c|c|c|}
\hline 921 & $F$ & 44 & C & $\begin{array}{l}9.7 \\
x\end{array}$ & $\begin{array}{l}919 \\
452\end{array}$ & $\begin{array}{l}599 \\
019\end{array}$ & 49637 & No FU \\
\hline
\end{tabular}

\begin{tabular}{|c|c|c|c|c|c|c|c|c|c|c|c|}
\hline \multirow[t]{2}{*}{1121} & $\mathrm{~F}$ & 27 & C & $\begin{array}{l}8.0 \\
x\end{array}$ & $\begin{array}{l}126 \\
868\end{array}$ & $\begin{array}{l}90 \\
889\end{array}$ & 8203 & 2 & $\begin{array}{l}394 \\
752\end{array}$ & $\begin{array}{l}283 \\
697\end{array}$ & 25273 \\
\hline & & & & & & Page & 29 & & & & \\
\hline
\end{tabular}




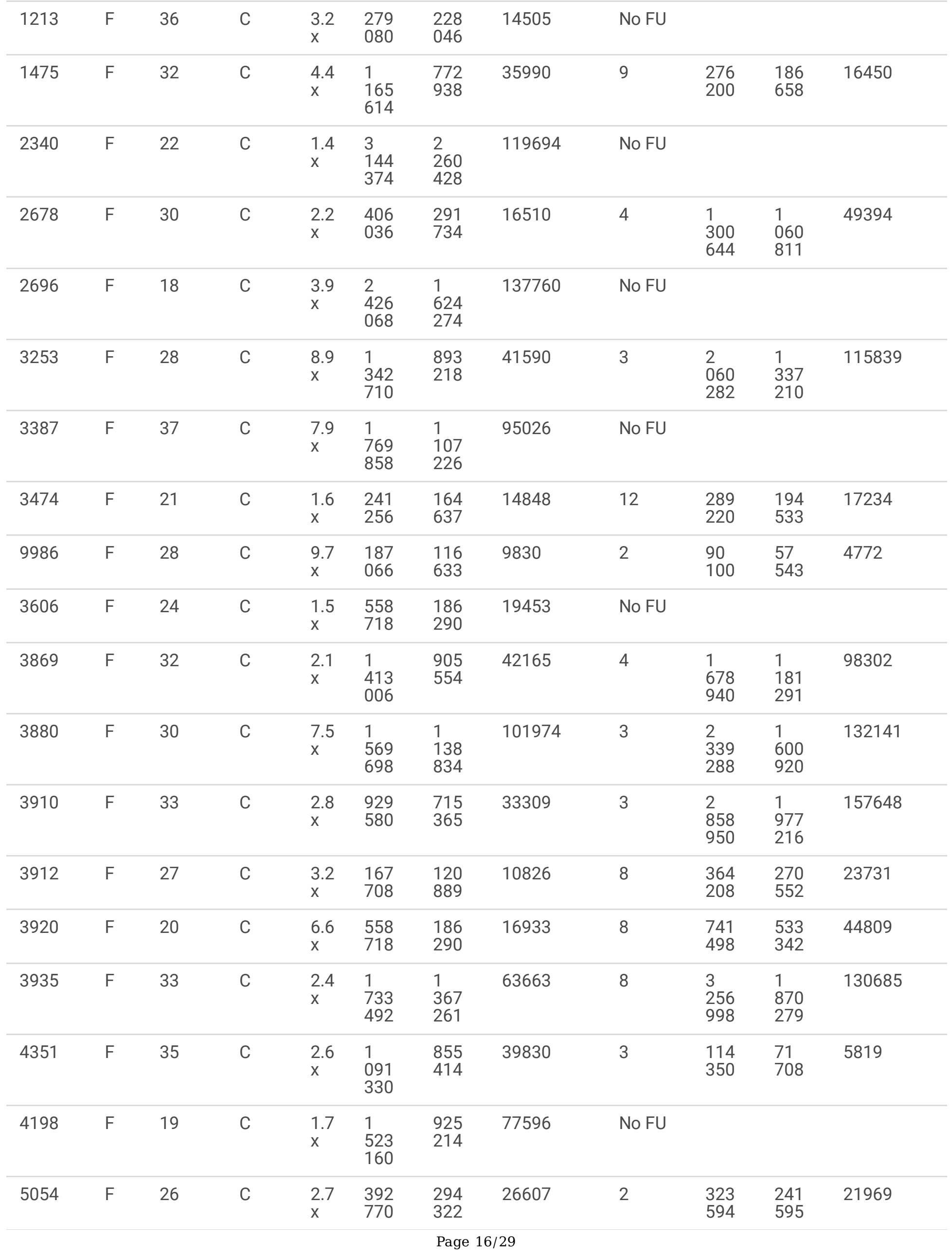




\begin{tabular}{|c|c|c|c|c|c|c|c|c|c|c|c|}
\hline 6380 & $F$ & 25 & $C$ & $\begin{array}{l}1.1 \\
x\end{array}$ & $\begin{array}{l}354 \\
870\end{array}$ & $\begin{array}{l}254 \\
132\end{array}$ & 23050 & 4 & $\begin{array}{l}229 \\
160\end{array}$ & $\begin{array}{l}156 \\
127\end{array}$ & 13011 \\
\hline 6565 & $\mathrm{~F}$ & 28 & $C$ & $\begin{array}{l}5.6 \\
x\end{array}$ & $\begin{array}{l}1 \\
827 \\
778\end{array}$ & $\begin{array}{l}1 \\
280 \\
993\end{array}$ & 76473 & 3 & $\begin{array}{l}121 \\
716\end{array}$ & $\begin{array}{l}95 \\
006\end{array}$ & 8145 \\
\hline 6671 & $\mathrm{~F}$ & 35 & $C$ & $\begin{array}{l}1.4 \\
x\end{array}$ & $\begin{array}{l}935 \\
030\end{array}$ & $\begin{array}{l}676 \\
975\end{array}$ & 40433 & No FU & & & \\
\hline 6649 & $\mathrm{~F}$ & 32 & $C$ & $\begin{array}{l}2.1 \\
x\end{array}$ & $\begin{array}{l}1 \\
163 \\
568\end{array}$ & $\begin{array}{l}755 \\
545\end{array}$ & 65939 & 2 & $\begin{array}{l}1 \\
482 \\
096\end{array}$ & $\begin{array}{l}998 \\
909\end{array}$ & 83275 \\
\hline 6640 & $\mathrm{~F}$ & 37 & $C$ & $\begin{array}{l}3.0 \\
x\end{array}$ & $\begin{array}{l}376 \\
388\end{array}$ & $\begin{array}{l}248 \\
289\end{array}$ & 21017 & 5 & $\begin{array}{l}1 \\
471 \\
394\end{array}$ & $\begin{array}{l}1 \\
041 \\
570\end{array}$ & 93224 \\
\hline 6596 & $\mathrm{~F}$ & 31 & $\mathrm{C}$ & $\begin{array}{l}3.8 \\
x\end{array}$ & $\begin{array}{l}1 \\
318 \\
526\end{array}$ & $\begin{array}{l}1 \\
082 \\
538\end{array}$ & 50406 & 8 & $\begin{array}{l}1 \\
346 \\
566\end{array}$ & $\begin{array}{l}910 \\
739\end{array}$ & 78503 \\
\hline 6509 & $M$ & 36 & $C$ & $\begin{array}{l}1.0 \\
x\end{array}$ & $\begin{array}{l}655 \\
472\end{array}$ & $\begin{array}{l}520 \\
480\end{array}$ & 23577 & No FU & & & \\
\hline 9915 & $\mathrm{~F}$ & 30 & $C$ & $\begin{array}{l}1.4 \\
x\end{array}$ & $\begin{array}{l}489 \\
752\end{array}$ & $\begin{array}{l}372 \\
610\end{array}$ & 21830 & No FU & & & \\
\hline 9895 & $\mathrm{~F}$ & 31 & $C$ & $\begin{array}{l}4.8 \\
x\end{array}$ & $\begin{array}{l}458 \\
108\end{array}$ & $\begin{array}{l}328 \\
446\end{array}$ & 18433 & No FU & & & \\
\hline 9854 & $\mathrm{~F}$ & 20 & $C$ & $\begin{array}{l}1.2 \\
x\end{array}$ & $\begin{array}{l}393 \\
220\end{array}$ & $\begin{array}{l}336 \\
159\end{array}$ & 20018 & No FU & & & \\
\hline 8828 & $\mathrm{~F}$ & 27 & $C$ & $\begin{array}{l}4.1 \\
x\end{array}$ & $\begin{array}{l}1 \\
331 \\
066\end{array}$ & $\begin{array}{l}985 \\
767\end{array}$ & 45900 & 14 & $\begin{array}{l}94 \\
018\end{array}$ & $\begin{array}{l}59 \\
609\end{array}$ & 5106 \\
\hline 7959 & $\mathrm{~F}$ & 40 & $C$ & $\begin{array}{l}1.4 \\
x\end{array}$ & $\begin{array}{l}538 \\
128\end{array}$ & $\begin{array}{l}453 \\
795\end{array}$ & 23053 & No FU & & & \\
\hline 6990 & $\mathrm{~F}$ & 26 & $C$ & $\begin{array}{l}1.7 \\
x\end{array}$ & $\begin{array}{l}143 \\
560\end{array}$ & $\begin{array}{l}101 \\
490\end{array}$ & 9056 & 6 & $\begin{array}{l}179 \\
342\end{array}$ & $\begin{array}{l}136 \\
949\end{array}$ & 12630 \\
\hline
\end{tabular}

ID - identity, $\mathrm{M}$ = male; $\mathrm{F}$ = female; HIV = human immunodeficiency virus; $\mathrm{E}$ = early HIV infection; $\mathrm{C}$ = chronic HIV infection; $\mathrm{VL}=$ viral load; $\mathrm{x}=$ times; $\mathrm{FU}=$ follow-up

Table 2: Nonsynonymous mutations in Pol CTL epitopes assessed from Sanger consensus sequences 
Distribution of mutation by stage of infection

\begin{tabular}{|c|c|c|c|c|c|c|}
\hline polprotein & Epitope position & $\begin{array}{l}\text { Wild type CTL } \\
\text { epitope }\end{array}$ & $\begin{array}{l}\text { Escape CTL } \\
\text { mutation }\end{array}$ & $\begin{array}{l}\text { Early HIV } \\
\text { samples: } n=15 \\
(\%)\end{array}$ & $\begin{array}{l}\text { Chronic HIV } \\
\text { samples: } n=34 \text { (\%) }\end{array}$ & $\begin{array}{l}\mathrm{P}- \\
\text { value }\end{array}$ \\
\hline \multirow[t]{2}{*}{ PR } & PR $(11-20)$ & VTIKIGGQLK & I15V & 73,3 & 59,4 & 0,345 \\
\hline & PR (30 - 38) & DTVLED $\underline{M N L}$ & M36I/L & 98 & 79 & 0,702 \\
\hline \multirow[t]{5}{*}{ RT } & RT $(33-41)$ & ALVEEICTEM & V35T/K/M & 100 & 100 & N/A \\
\hline & RT $(202-210)$ & IEELRQHLL & I202V & 10 & 17,7 & 1,000 \\
\hline & RT (269 - 277) & QIYAGIKVK & A272P/G/S* & 80 & 55 & 0,345 \\
\hline & $\begin{array}{l}\text { Not within } \\
\text { epitope RT } 329\end{array}$ & $\underline{I}$ & I329V/L & 20 & 5,8 & 0,160 \\
\hline & RT (375 - 383) & IAMESIVIW & I375V & 20 & 11,8 & 0,660 \\
\hline \multirow[t]{3}{*}{ IN } & $\begin{array}{l}\text { Not within } \\
\text { epitope IN } 206\end{array}$ & $\mathbf{I}$ & T206S & 20 & 15 & 0,687 \\
\hline & IN (218 - 227) & TKIQNFRVYY & K219N/Q & 10 & 17,6 & 1,000 \\
\hline & IN (278 - 288) & DDCVASRQDED & S283D/G & 100 & 95 & 1,000 \\
\hline
\end{tabular}

*Codon had significant dN/dS ratio ( $p$-value $=0.001) . C T L=$ cytotoxic T-lymphocyte; $N / A=$ not applicable; $P R=$ protease; $\mathrm{RT}$ = reverse transcriptase; $\mathrm{IN}=$ integrase; $\mathrm{Pol}=$ polymerase.

Table 3: Frequently targeted Pol CTL epitopes and their predicted HLA alleles 
Early HIV infection

\begin{tabular}{|c|c|c|c|c|}
\hline $\begin{array}{l}\text { Epitope } \\
\text { position }\end{array}$ & $\begin{array}{l}\text { Wild type and variant } \\
\text { epitope sequences }\end{array}$ & $\begin{array}{l}\text { Subtype } \\
\text { identified for } \\
\text { epitope }\end{array}$ & Predicted HLA & Participants \\
\hline $\begin{array}{l}\text { PR (68- } \\
76)\end{array}$ & $\begin{array}{l}\text { GKKAIGTVL } \\
\text { E............. } \\
\text {................ } \\
\text {................ }\end{array}$ & $\begin{array}{l}\text { Subtype B } \\
\text { and C }\end{array}$ & $\begin{array}{l}B * 15: 03 ; B * 13: 02 \\
C * 02\end{array}$ & $3469,8047,6743$ \\
\hline $\begin{array}{l}\text { RT } \\
(139- \\
149)\end{array}$ & $\begin{array}{l}\text { TPGIRYQYNVL } \\
\ldots \ldots \ldots \ldots \ldots \ldots . . . \\
\ldots \ldots \ldots \ldots \ldots \ldots . . .\end{array}$ & Subtype C & $B * 81: 01 ; B * 81$ & $6737,261,9049$ \\
\hline $\begin{array}{l}\text { RT } \\
(243- \\
251)\end{array}$ & $\begin{array}{l}\text { PIQLPEKDS } \\
\text {.............. } \\
\text {................ }\end{array}$ & Subtype C & Not reported & 6737,6743 \\
\hline $\begin{array}{l}\text { RT } \\
(268- \\
277)\end{array}$ & $\begin{array}{l}\text { SQIYPGIKVR } \\
\ldots \ldots . . . \ldots \ldots \ldots \\
\ldots \ldots \ldots \ldots \ldots . . . N\end{array}$ & Subtype C & $\underline{A}$ *74:01 & 6743,6638 \\
\hline $\begin{array}{l}\text { RT } \\
\text { (485- } \\
493)\end{array}$ & $\begin{array}{l}\text { ALQDSGLEV } \\
\ldots \ldots . . . . . \ldots \ldots\end{array}$ & Subtype B & $A * 02: 01 ; A * 02$ & 8047,6743 \\
\hline $\begin{array}{l}\text { RT } \\
(516- \\
525)\end{array}$ & $\begin{array}{c}\text { ELVNQIIEQL } \\
\ldots \ldots . . . \ldots \ldots \ldots \\
\ldots \ldots \ldots \ldots . . . . . \\
\ldots \ldots \ldots \ldots . . .\end{array}$ & Not reported & $A^{* 02}$ & $9049,8047,6743$ \\
\hline $\begin{array}{l}\text { IN }(20- \\
28)\end{array}$ & $\begin{array}{l}\text { RAMASDFNL } \\
\text { K............... } \\
\ldots \ldots . . . . \ldots \ldots \ldots\end{array}$ & Not reported & $A * 02: 01 ; A * 02$ & $6582,3469,6743$ \\
\hline $\begin{array}{l}\text { IN (123- } \\
131)\end{array}$ & 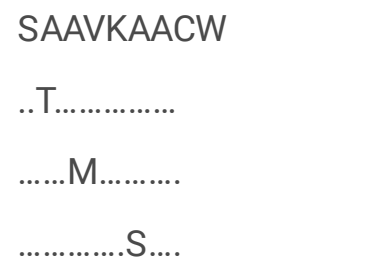 & Subtype C & $\underline{B * 58: 01}$ & $7084,9049,8047,6743$ \\
\hline $\begin{array}{l}\text { IN (135- } \\
146)\end{array}$ & $\begin{array}{l}\text { IQQEFGIPYNPQ } \\
\text {.H................ } \\
\ldots \ldots \ldots \ldots \ldots . . . . . . . .\end{array}$ & Subtype C & $B * 15: 03$ & 2504,8047 \\
\hline $\begin{array}{l}\text { IN (213- } \\
220)\end{array}$ & $\begin{array}{l}\text { LQKQITKI } \\
\text {.............. }\end{array}$ & Subtype B & $B * 52: 01$ & $9049,8047,8575$ \\
\hline
\end{tabular}




$\begin{array}{llll}\text { IN }(263- & \text { RKAKIIKDY } & \text { Subtype C } & \text { B*15:03 } \\ 271) & \\ & \\ & \text {......R........ } \\ & \\ & \text {.........R.... }\end{array}$

\section{Chronic HIV infection}

\begin{tabular}{|c|c|c|c|c|}
\hline $\begin{array}{l}\text { Epitope } \\
\text { position }\end{array}$ & $\begin{array}{l}\text { Wild type and } \\
\text { variant epitope } \\
\text { sequences }\end{array}$ & $\begin{array}{l}\text { Subtype identified for } \\
\text { epitope }\end{array}$ & Predicted HLA & Participants \\
\hline $\begin{array}{l}\text { PR }(11- \\
20)\end{array}$ & $\begin{array}{l}\text { VTIKIGGQLK } \\
\text {................. } \\
\text {................. }\end{array}$ & Subtype B and C & $A * 03: 01 ; A * 11: 01$ & $\begin{array}{l}\text { 6990, 641, 3253, 3910, 3912, } \\
\text { 3920, }\end{array}$ \\
\hline $\begin{array}{l}\text { PR (30- } \\
38)\end{array}$ & $\begin{array}{l}\text { DTVLEEMNL } \\
\ldots \ldots \ldots . . \mathrm{D} \ldots \ldots\end{array}$ & Subtype A and B & 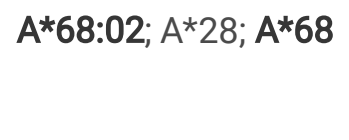 & $3253,6565,9986$ \\
\hline $\begin{array}{l}\text { PR }(34- \\
42)\end{array}$ & $\begin{array}{l}\text { EEINLPGKW } \\
\ldots \ldots \ldots . . . . . . .\end{array}$ & Subtype A, C and D & $A * 11 ; A * 68 ; B * 08$ & 843,3880 \\
\hline $\begin{array}{l}\text { PR }(42- \\
50)\end{array}$ & $\begin{array}{l}\text { WKPKMIGGI } \\
\ldots \text { R............ } \\
\text {.......R......... }\end{array}$ & Subtype B & Cw3 & $6649,6990,1121,1475,3253$ \\
\hline $\begin{array}{l}\text { PR (56- } \\
66)\end{array}$ & $\begin{array}{l}\text { VRQYDQIPIEI } \\
\text { F................. } \\
\text {.................... }\end{array}$ & Subtype B & $B * 13$ & $6649,3253,3920,3935,6565$ \\
\hline $\begin{array}{l}\text { PR }(68- \\
76)\end{array}$ & $\begin{array}{l}\text { GKKAIGTVL } \\
\ldots . . . \mathrm{Q}_{\ldots \ldots \ldots . . .} \\
\ldots \ldots \ldots . . . . . .\end{array}$ & Subtype B and C & $\begin{array}{l}B * 15 ; B * 15: 03 \\
B * 13: 02 ; C * 02\end{array}$ & 3253, 3910, 3869, 5054, 9986 \\
\hline $\begin{array}{l}\text { PR }(80- \\
90)\end{array}$ & $\begin{array}{l}\text { TPVNIIGRNML } \\
\text {................... } \\
\text {...................M }\end{array}$ & Subtype C & $B * 81: 01 ; B * 81$ & $\begin{array}{l}1475,3253,3910,3920,5054 \\
6596\end{array}$ \\
\hline $\begin{array}{l}\text { PR }(91- \\
99)\end{array}$ & $\begin{array}{l}\text { TQIGCTLNF } \\
\ldots . . . \ldots \ldots \ldots . . . \\
\ldots . . . . . . . . . . .\end{array}$ & Subtype B and C & $B * 15: 01 ; B * 15: 03$ & $639,1475,3253,9986$ \\
\hline $\begin{array}{l}\text { PR (99)- } \\
\text { RT (8) }\end{array}$ & $\begin{array}{l}\text { FPISPIETVP } \\
\ldots \ldots . . . \ldots \ldots \ldots \\
\ldots \ldots \ldots . . . . . . . . \\
\ldots \ldots \ldots \ldots . . . . .\end{array}$ & Subtype B & $B \star 54: 01$ & $\begin{array}{l}6649,641,843,1121,1475, \\
3253,3935,2678\end{array}$ \\
\hline $\begin{array}{l}\mathrm{RT}(57- \\
66)\end{array}$ & NTPVFAIKKK & Subtype B and C & $A^{*} 11 ; A^{*} 68 ; B * 08$ & 6649,3253 \\
\hline
\end{tabular}


..T........

\begin{tabular}{|c|c|c|c|c|}
\hline $\begin{array}{l}\text { RT (73- } \\
82)\end{array}$ & KLVDFRELNK & Subtype A, B, C and D & $\begin{array}{l}A * 03: 01 ; A * 34 ; A * 29 \\
B * 18 ; B * 80\end{array}$ & $641,3910,3869,6565$ \\
\hline
\end{tabular}

\begin{tabular}{|c|c|c|c|c|}
\hline $\begin{array}{l}\text { RT } \\
(105- \\
113)\end{array}$ & $\begin{array}{l}\text { SVTVLDVGD } \\
\text {..A.............. }\end{array}$ & Subtype B & Not reported & $843,3920,3935$ \\
\hline $\begin{array}{l}\text { RT } \\
(113- \\
120)\end{array}$ & $\begin{array}{l}\text { DAYFSVPL } \\
\text {.............. } \\
\text {................ }\end{array}$ & Subtype C & $A * 24 ; B * 51: 01 ; B \star 51$ & 1475,3253 \\
\hline $\begin{array}{l}\text { RT } \\
(118- \\
127)\end{array}$ & $\begin{array}{l}\text { VLPDEGFRKY } \\
\text {................... }\end{array}$ & Subtype C & $\begin{array}{l}B * 35: 01 ; B * 35: 02 \\
B * 42: 01\end{array}$ & 1121,8828 \\
\hline $\begin{array}{l}\text { RT } \\
(136- \\
144)\end{array}$ & $\begin{array}{l}\text { NNETPGIRY } \\
\ldots . . . . \ldots \ldots \ldots . . . . \\
\ldots \ldots \ldots \ldots . . . . . \\
\ldots \ldots \ldots \ldots . . . \mathrm{K} . .\end{array}$ & Subtype C & $B * 18: 01 ; B * 18$ & $6649,1475,3869,3920$ \\
\hline
\end{tabular}

$\begin{array}{lllll}\text { RT } & \text { LPQGWKGSPAl } & \text { Subtype C } & \text { B*39:10; B*42:01 } & 3253,3910,9986 \\ (149- & & & \\ 159) & \ldots \ldots \ldots \ldots . . . . . . . . . . & & \end{array}$

S.

\begin{tabular}{|c|c|c|c|c|}
\hline $\begin{array}{l}\text { RT } \\
(159- \\
167)\end{array}$ & $\begin{array}{l}\text { IFQSSMTKIL } \\
\text {................F. }\end{array}$ & Subtype A, B and C & Not reported & 843,5054 \\
\hline $\begin{array}{l}\text { RT } \\
(171- \\
181)\end{array}$ & 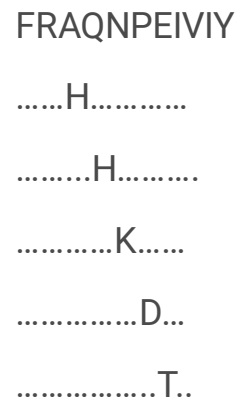 & Not reported & Not reported & $\begin{array}{l}6649,843,1475,3253,3474, \\
3869,3920,3935,5054\end{array}$ \\
\hline $\begin{array}{l}\text { RT } \\
(181- \\
189)\end{array}$ & YQYMDDLYV & Subtype A, B, C and D & $A^{*} 02: 01 ; A^{*} 02$ & 641,6565 \\
\hline $\begin{array}{l}\text { RT } \\
(192- \\
202)\end{array}$ & $\begin{array}{l}\text { DLEIGQHRTKI } \\
\text { G................ } \\
\ldots \ldots . . . . \ldots \ldots \ldots . . . \\
\ldots \ldots \ldots \ldots . . . \\
. . . . . . . . . .\end{array}$ & Subtype B & $A * 03$ & $\begin{array}{l}6649,6990,1121,3920,3935, \\
6596,8828\end{array}$ \\
\hline RT & EELREHLLKW & Subtype C & $B * 44: 03$ & $6990,1121,3253,3474,3869$, \\
\hline
\end{tabular}


..K...

........

R ...............

RT ELHPDRWTV Subtype B and C Not reported $\quad$ 641, 1121, 3912, 3935, 6565

…...............

.................

$\begin{array}{llll}\text { RT } & \text { TVQPIVLPE } & \text { Subtype B } & \text { Not reported }\end{array}$

248) $\quad$................

(..............

$\begin{array}{llll}\text { RT } & \text { AENREILKE } & \text { Subtype B } & \text { Not reported }\end{array}$

312) $\quad$................

…............

\begin{tabular}{|c|c|c|c|}
\hline VYYDPSKDLIA & Subtype C & Not reported & $\begin{array}{l}6990,1121,1475,3253,3910 \text {, } \\
3935\end{array}$ \\
\hline
\end{tabular}

327)

…...................

S..............

T..........

E....

...V.

$\begin{array}{llll}\text { RT } & \text { IQKQGQGQWTY } & \text { Subtype B } & \text { B*39:01 5054, 6565, 3387, } 6509\end{array}$

339)

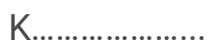

N............

QIYQEPFKNLKTG Subtype B

$A^{*} 11 ; A^{* 11: 01}$

$641,843,1475,3474,3910$,

RT
$(340-$

352)

..V. 6380

R...

RT KMRTAHTNDVK Subtype B

(356-

366)

...R.

.....K

E.
$A^{\star 03: 01 ;} A^{\star 03}$

$6649,6990,641,1121,1475$, $3253,3920,5054,9986$

A..

RT

(367-

375)
Subtype C ….............

R... 
M...

\begin{tabular}{|c|c|c|c|c|}
\hline $\begin{array}{l}\text { RT } \\
\text { (379- } \\
388)\end{array}$ & $\begin{array}{l}\text { SIVIWGKTPK } \\
\ldots \ldots \ldots \ldots . . . . . . \\
\ldots \ldots \ldots \ldots . . . . \mathrm{R}\end{array}$ & Subtype B & $A^{\star} 11: 01$ & $\begin{array}{l}3880,6990,843,1121,3474, \\
3920,3935,9986\end{array}$ \\
\hline $\begin{array}{l}\text { RT } \\
\text { (397- } \\
406)\end{array}$ & $\begin{array}{l}\text { TWETWWTEYW } \\
\text {.....G.................. }\end{array}$ & Subtype B & $B * 44$ & $6640,1121,3912,3920$ \\
\hline $\begin{array}{l}\text { RT } \\
\text { (416- } \\
425)\end{array}$ & $\begin{array}{l}\text { FVNTPPLVKL } \\
\ldots \ldots \ldots \ldots \ldots \ldots . . . \\
\ldots \ldots \ldots \ldots \ldots . . .\end{array}$ & Subtype C & $B * 07$ & $641,3253,3935,7959$ \\
\hline $\begin{array}{l}\text { RT } \\
\text { (432- } \\
441)\end{array}$ & 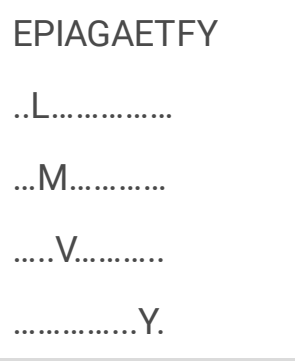 & Subtype C & $B * 35: 01$ & $\begin{array}{l}641,843,3910,3869,5054 \\
6509,7959\end{array}$ \\
\hline $\begin{array}{l}\text { RT } \\
\text { (448- } \\
457)\end{array}$ & $\begin{array}{l}\text { RETKIGKAGY } \\
\ldots \ldots \ldots \text { R.......... } \\
\ldots \ldots \ldots . . . \ldots \ldots \ldots \\
\ldots \ldots \ldots \ldots . . . . . . .\end{array}$ & Subtype B & $A^{*} 29$ & $\begin{array}{l}843,1121,3253,3869,3920 \\
3935,9986\end{array}$ \\
\hline $\begin{array}{l}\text { RT } \\
\text { (461- } \\
469)\end{array}$ & $\begin{array}{l}\text { KGRQKIVTL } \\
\text { R.............. } \\
\ldots \ldots \ldots \ldots . . . . . . \\
\ldots \ldots \ldots \ldots \ldots . . . \\
\ldots\end{array}$ & Subtype B & $B^{\star} 08: 01$ & $\begin{array}{l}1121,1475,3910,3920,3935, \\
9986,6509,7959,9854\end{array}$ \\
\hline
\end{tabular}

\begin{tabular}{|c|c|c|c|c|}
\hline $\begin{array}{l}\text { RT } \\
\text { (468- } \\
476)\end{array}$ & $\begin{array}{c}\text { SLETTNQK } \\
\ldots \ldots \ldots \ldots . . . \mathrm{R}\end{array}$ & Subtype C & $A^{*} 74: 01$ & $6640,6990,1475,6509,7959$ \\
\hline $\begin{array}{l}\text { RT } \\
\text { (477- } \\
486)\end{array}$ & $\begin{array}{l}\text { TELQAIQLAL } \\
\ldots \ldots . . . . . \ldots \ldots . . .\end{array}$ & Subtype C & $B * 18: 01$ & $641,843,3910$ \\
\hline $\begin{array}{l}\text { RT } \\
\text { (491- } \\
501)\end{array}$ & $\begin{array}{l}\text { SEVNIVTDSQY } \\
\ldots \ldots . . . \mathrm{V} \ldots \ldots \ldots \ldots . . . . \\
\ldots \ldots \ldots . . . . . . . . . .\end{array}$ & Subtype C & $\underline{B * 44: 03}$ & $3880,6649,6565$ \\
\hline $\begin{array}{l}\text { RT } \\
\text { (509- } \\
518)\end{array}$ & $\begin{array}{l}\text { QPDKSESELV } \\
\ldots \ldots \ldots . . . \ldots \ldots . .\end{array}$ & Subtype A, B, C and D & $B * 07$ & 1121,3869 \\
\hline RT & NQIIEQLIKK & Subtype B & Not reported & $6640,6649,843,3869,5054$ \\
\hline
\end{tabular}


...Q...

\begin{tabular}{|c|c|c|c|c|}
\hline $\begin{array}{l}\text { RT } \\
(526- \\
534)\end{array}$ & $\begin{array}{l}\text { IKKEKIYLA } \\
\ldots \ldots . . . \ldots \ldots \ldots \\
\ldots \ldots \ldots . . . . . . . . \\
\ldots \ldots \ldots \ldots . . .\end{array}$ & Subtype B & Not reported & $6649,641,3920,3935,9986$ \\
\hline $\begin{array}{l}\text { RT } \\
(550- \\
559)\end{array}$ & $\begin{array}{l}\text { KLVSQGIRKV } \\
\text { R................ } \\
\text {.................. }\end{array}$ & Subtype A, B, C and D & $A * 02: 01$ & $639,1121,3869,9986$ \\
\hline $\begin{array}{l}\text { IN }(22- \\
31)\end{array}$ & 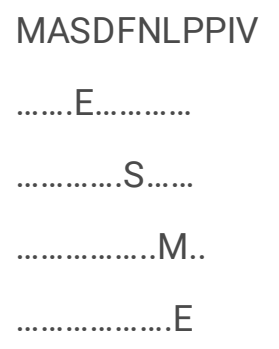 & Not reported & $A * 02$ & $\begin{array}{l}6649,641,843,1121,1475, \\
3910,3869,3920,3935,4351, \\
5054,6565\end{array}$ \\
\hline $\begin{array}{l}\text { IN (33- } \\
43)\end{array}$ & 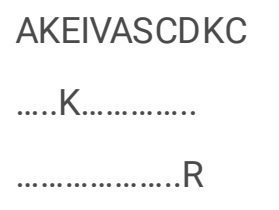 & Not reported & Not reported & $6649,6990,3253,3920,2678$ \\
\hline $\begin{array}{l}\text { IN (68- } \\
76)\end{array}$ & $\begin{array}{l}\text { LEGKIILVA } \\
\text {............... }\end{array}$ & Subtype B & $B * 40: 06$ & $6990,639,3253$ \\
\hline $\begin{array}{l}\text { IN (78- } \\
86)\end{array}$ & $\begin{array}{l}\text { HVASGYIEA } \\
\text { E.............. } \\
\ldots . . . \text { T........... } \\
\ldots \ldots . \text { T......... }\end{array}$ & Subtype B & $B * 54: 01$ & $1121,3935,6565$ \\
\hline $\begin{array}{l}\text { IN (101- } \\
105)\end{array}$ & $\begin{array}{l}\text { ILKLAGRWPVK } \\
\text { A................. } \\
\text {..................... } \\
\ldots \ldots \ldots \ldots \ldots \ldots . . \mathrm{R}\end{array}$ & Subtype C & $A * 03: 01$ & $\begin{array}{l}1121,1475,3474,3869,5054, \\
2678\end{array}$ \\
\hline $\begin{array}{l}\text { IN (114- } \\
123)\end{array}$ & $\begin{array}{l}\text { HTDNGSNFTS } \\
\text {.................. }\end{array}$ & Subtype B & $\mathrm{CW}^{* 05}$ & 1121,3869 \\
\hline $\begin{array}{l}\text { IN (123- } \\
132)\end{array}$ & $\begin{array}{l}\text { SAAVKAACWW } \\
\text {..T................ } \\
\text {...T................ } \\
\ldots \ldots \ldots \ldots \ldots . . . . . .\end{array}$ & Subtype C & $B * 58: 01$ & $3880,641,843,3935,8828$ \\
\hline $\begin{array}{l}\text { IN (135- } \\
143)\end{array}$ & $\begin{array}{l}\text { IQQEFGIPYNPQ } \\
\ldots \ldots \ldots \ldots . . . . . . .\end{array}$ & Subtype C & $B * 15: 03$ & 1475,6565 \\
\hline
\end{tabular}


.Y...

\begin{tabular}{|c|c|c|c|c|}
\hline $\begin{array}{l}\text { IN (164- } \\
172)\end{array}$ & $\begin{array}{l}\text { QVRDQAEHL } \\
\ldots . \mathrm{M} \ldots \ldots \ldots \ldots . . . \\
\ldots . . . \mathrm{L} \ldots \ldots \ldots \ldots . . . \\
\ldots \ldots . . . . \ldots \ldots \ldots . .\end{array}$ & Subtype C & $A * 02: 05$ & 3869,3920 \\
\hline $\begin{array}{l}\text { IN (185- } \\
194)\end{array}$ & 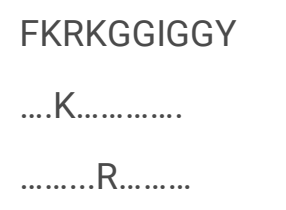 & Subtype A, B and C & $\begin{array}{l}B * 15: 03 ; B * 27: 05 \\
C * 01\end{array}$ & 3920,3935 \\
\hline $\begin{array}{l}\text { IN (206- } \\
213)\end{array}$ & $\begin{array}{l}\text { TDIQTKEL } \\
\ldots . \text { E.......... } \\
\ldots \text { T........ } \\
\text {............ }\end{array}$ & Subtype B & $B * 40: 02$ & $3935,6380,6565$ \\
\hline $\begin{array}{l}\text { IN (213- } \\
220)\end{array}$ & $\begin{array}{l}\text { LQKQITKI } \\
\ldots \ldots . . . . . \ldots \\
\ldots \ldots \ldots . . . . . .\end{array}$ & Subtype B & $B * 52: 01$ & 843,1475 \\
\hline $\begin{array}{l}\text { IN }(241- \\
250)\end{array}$ & $\begin{array}{l}\text { LLWKGEGAVV } \\
\text {................... }\end{array}$ & Not reported & $A * 02: 01$ & 6640,641 \\
\hline $\begin{array}{l}\text { IN (259- } \\
268)\end{array}$ & $\begin{array}{l}\text { VPRRKVKII } \\
\text {.............. } \\
\text {............... }\end{array}$ & Subtype B and C & $B * 08: 01$ & $843,3253,3910,3912,5054$ \\
\hline $\begin{array}{l}\text { IN }(278- \\
288)\end{array}$ & 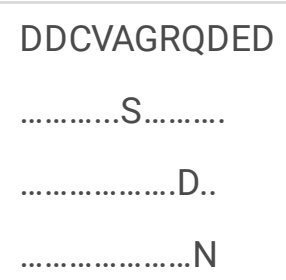 & Not reported & Not reported & $3253,3910,3935,8828$ \\
\hline
\end{tabular}

HLA alleles in boldface are those that have been identified (reported) in South Africa or southern Africa [11,28-30]. Alleles underlined are those that were reported to be protective $[11,28-29,49,50]$. PR = protease; RT = reverse transcriptase; IN = integrase; $\mathrm{HLA}=$ human leukocyte antigen

\section{Figures}




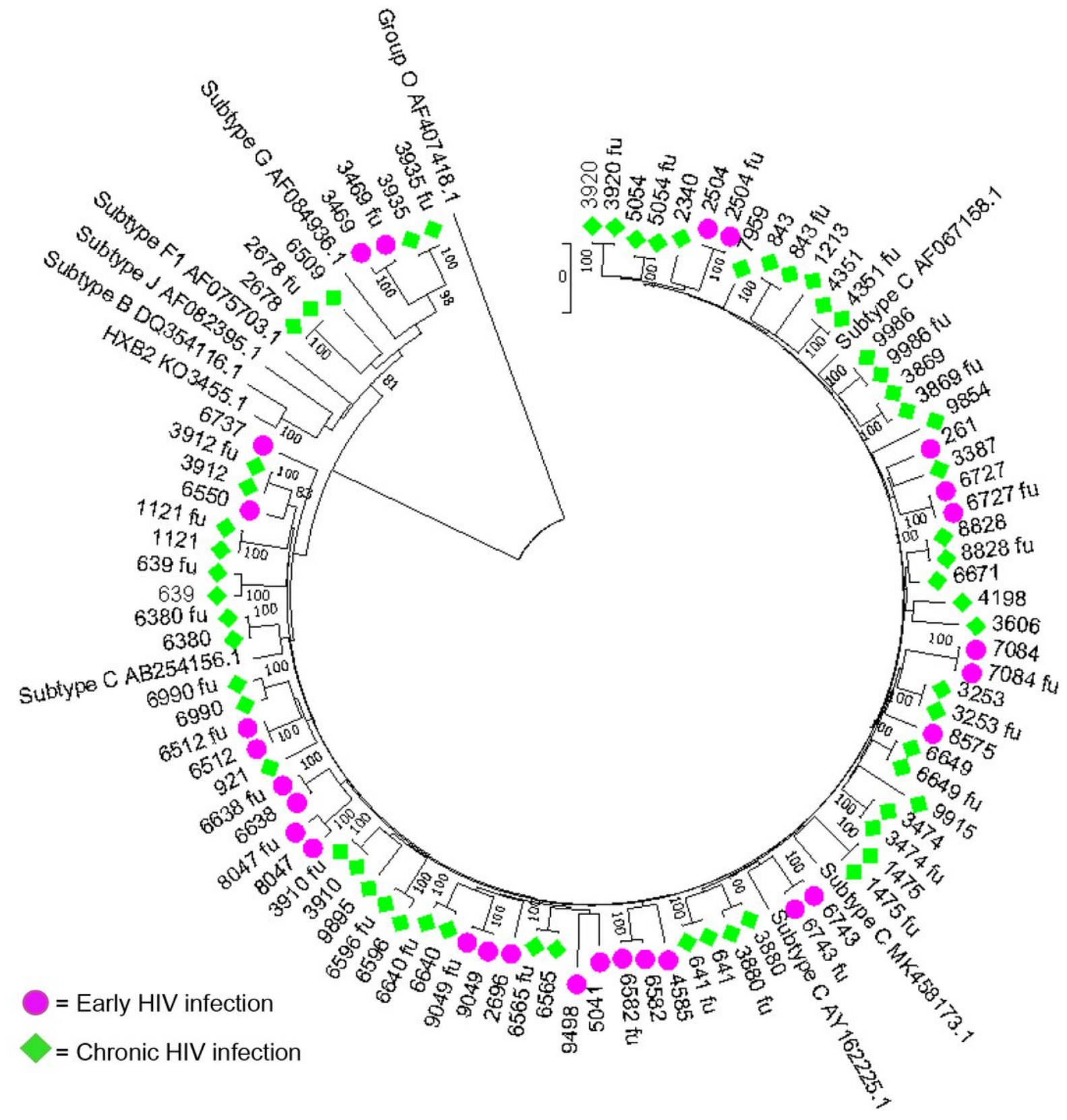

Figure 1

Neighbour-joining phylogenetic tree of all samples including sample pairs. Group 0 strain of HIV-1 was used for rooting. Only bootstrap values above $70 \%$ are shown. Baseline and follow-up (fu) sequences of the same participant correctly clustered. 
(A)

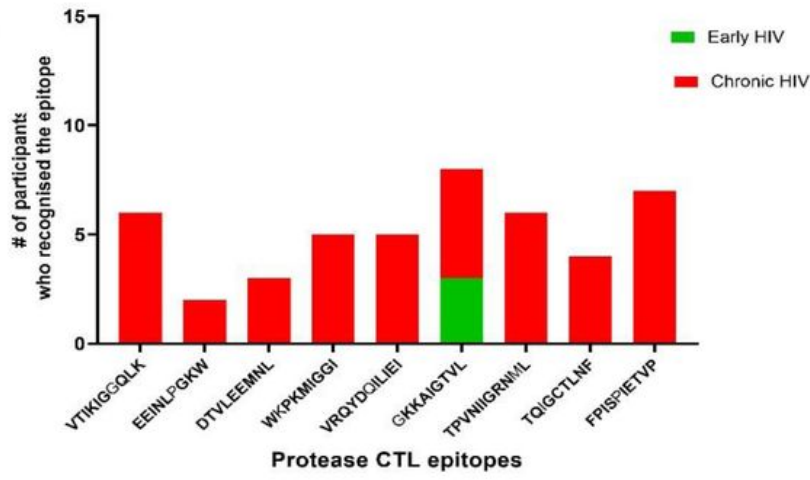

(B)

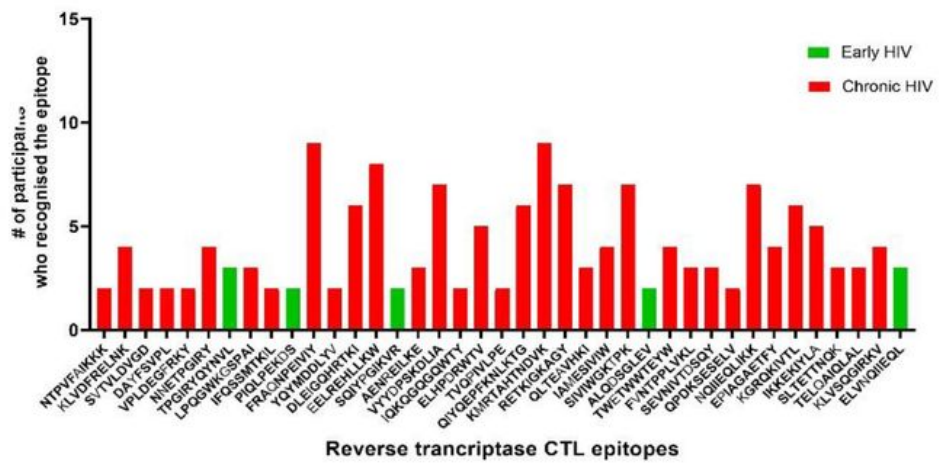

(C)

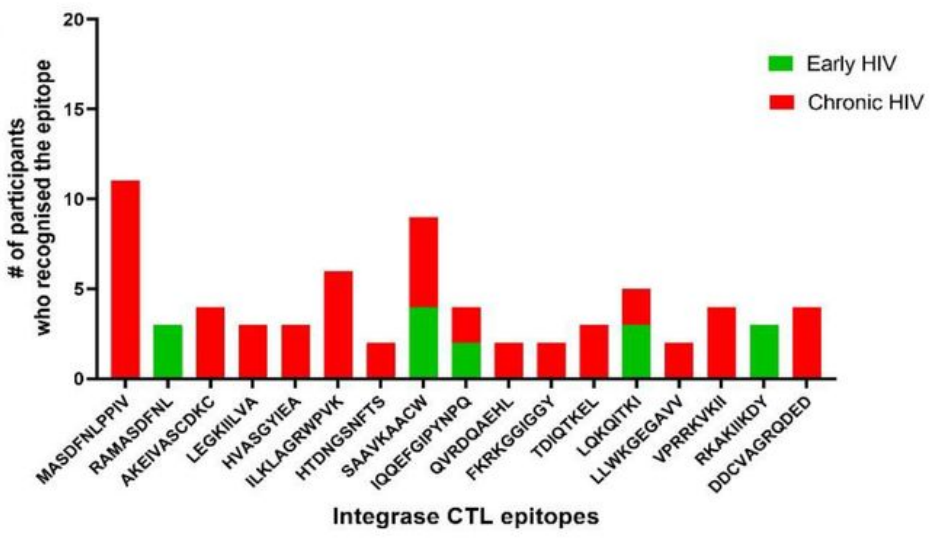

Figure 2

Frequently recognized Pol CTL epitopes in early and chronic HIV infection. These are epitopes that were recognized by more than one participant. (A) Epitopes within the protease (PR) region. (B) Epitopes within the reverse transcriptase (RT) region. (C) Epitopes within the integrase (IN) region. Many epitopes were located within RT and IN as compared to PR, and most were found in chronic HIV infection. CTL = cytotoxic T-lymphocytes. 
A) Early HIV infection

(i)

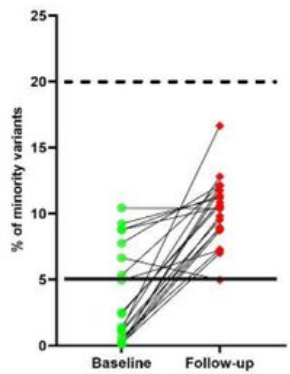

(iii)

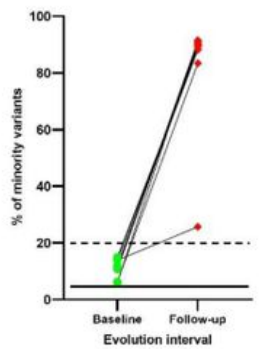

(ii)

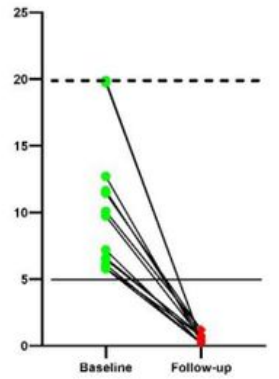

(iv)

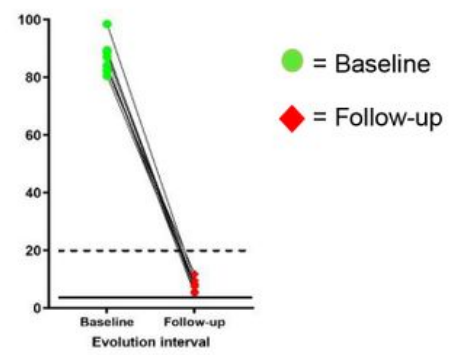

B) Chronic HIV infection

(i)

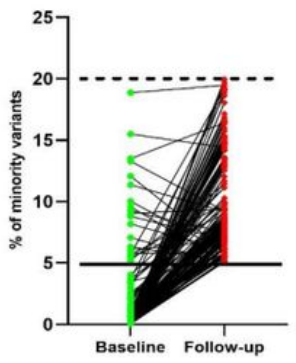

(iii)

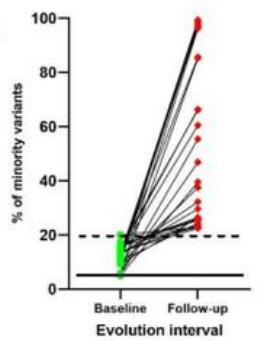

(ii)

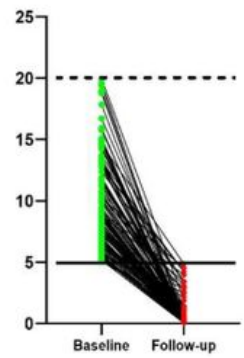

(iv)

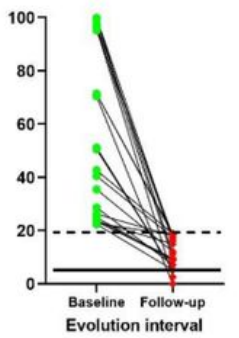

$=$ Baseline

= Follow-up

Figure 3

Dynamics of minority variants in sample pairs during (A) early HIV infection and (B) chronic HIV infection. (i) Some variants either increased in proportion between baseline and follow-up or remained at / above the detection limit of $5 \%$ (black solid line). (ii) Other variants decreased in proportion over time and were detected below $5 \%$ at follow-up. (iii) There were variants that increased in proportion over time to become majority variants and were thus maintained above $20 \%$ (black dotted line). (iv) Some minority variants that were detected at follow-up existed as majority variants at baseline. The median interval between baseline and follow-up sampling was 4 weeks (IQR: 3 - 8 weeks).

\section{Supplementary Files}

This is a list of supplementary files associated with this preprint. Click to download. 
- SupplementaryFigure1.pdf

- SupplementaryTable1.docx

- SupplementaryTable2.docx

- SupplementaryTable3.docx 